South Asian J. Food Technol. Environ., 5(1): 817-820 (2019)

ISSN 2394-5168(Print), 2454- 6445(online)

www.sweft.in

\title{
Conversion of agro-cum-catering waste to renewable energy
}

\author{
S. K. Goyal ${ }^{1 *}$, Suresh Chandra ${ }^{2}$ and Samsher ${ }^{2}$ \\ ${ }^{1}$ Deptt. of Farm Engg. (KVK), I. Ag. Scs., BHU, Barkachha, Mirzapur (U.P.) \\ ${ }^{2}$ Department of Agricultural Engineering \\ Sardar Vallabhbhai Patel University of Agriculture \& Technology, Meerut-250 110 (U P)
}

\begin{abstract}
$\underline{\text { Abstract }}$
Non-conventional energy sources are an eco friendly choice to fulfill the growing energy requirements. The waste of food processing industries, pulp \& paper industries, domestic and municipal waste, flowers waste, soiled and mutilated currency notes can be used for the energy generation. Flowers waste is anaerobically digested to produce the biogas. Electricity can be generated form the biogas with the help of an electricity generator. Soiled currency is shredded and briquettes are made which can be used for energy generation. Fruits and vegetable waste can be anaerobically digested in a digester with two gasholders to produce biogas. Slurry produced can be used as manure. The biogas produced from fruits and vegetable waste is about 2.5 times higher than biogas obtained from cattle dung.
\end{abstract}

Keywords: Renewable energy, catering waste, biomass, biogas.

Paper cited: Goyal, S.K., Chandra, S. and Samsher (2019). Conversion of agro-cum-catering waste to renewable energy. South Asian Journal of Food Technology and Environment, 5(1): 817-820.

\section{Introduction}

Energy an essential ingredient for the development and growth of any economy is scare nowadays. Various sources available for meeting the ever-growing energy requirements include hydro electrical, thermal, geothermal, nuclear, solar, wind, tidal and the biomass energy. Energy generated from the burning of the fossil fuel, coal, and by nuclear energy installations has adverse effect on the environment. Depletion of ozone layer is an outcome of our over dependence on the pollution generating source of energy. Nonconventional energy sources viz. solar, wind, tidal and the biomass energy are eco friendly sources and may prove a healthy solution of our growing energy requirements. Agricultural sector consumes a large amount of energy for the production of unit mass of food grain. The non-conventional energy sources may profitably replace the conventional energy input for farm operation. Potential of non-conventional energy sources needs to be harnessed to its greatest extent.

\section{Biogas potential from food waste}

TERI undertook a survey of quantity of waste generated in the marriage hall.. Table-1 showed results from the survey. Breakfast, lunch and dinner waste in the form of left over food and banana leaves was quantified as "Food waste". Vegetables peel; flower decorations, paper napkins, cups etc. were weighed collectively for the entire day and labeled "other waste".

For the day on which the hall was booked, the average food waste generated daily was $131.42 \mathrm{~kg}$ and the total waste generated daily was $190.10 \mathrm{~kg}$ hence about $69 \%$ of the total wastes generate is food wastes. An average of $80.75 \mathrm{~kg}$ of waste per day is generated throughout the year (Kavita et al., 1997). The 
waste generated mainly consists of biodegradable wastes, it was estimated that the total solids present in the waste is $12.11 \mathrm{~kg}$ /day of this $9 \%$ or $10.9 \mathrm{~kg}$ is constituted by total volatile solids, which account for biogas production. The biogas yield form this is 3.27 $\mathrm{m}^{3}$, equivalent to $1.42 \mathrm{~kg}$ of LPG.

\section{Energy generation from waste of fruits and vegetables processing}

Fruit and vegetables processing industries produce staggering quantities of waste every day. These wastes are jettisoned to the environment causing serious pollution problems. Besides these processing industries, especially the ones located in rural areas are invariably affected by scarcity of energy. Nand et al.(1997), at CFTRI, Mysore carried out an extensive research for production of biogas from waste materials obtained as a result of processing of mango, citrus, pineapple and tomato. The biogas produced from these waste is about 2.5 times higher than biogas obtained from cattle dung. The CFTRI technology for the preservation of fruits and vegetables waste makes ideal for community biogas plants (capacity $2.5-50 \mathrm{~m}^{3}$ ). The waste can be fed to digesters which normally operate on cattle dung $100 \mathrm{~kg}$ of dry feed gives $50 \mathrm{~m}^{3}$ of biogas (equivalent to $21.6 \mathrm{~kg} \mathrm{LPG}$ ). Table 2 reported the total availability of fruits and vegetables processing waste in India. Parameters for fruits and vegetables processing waste based plants of various capacities are given in Table 3.

Table-1: Total food waste and other waste generated at marriage hall

\begin{tabular}{|c|c|c|c|c|c|}
\hline \multirow{2}{*}{ Day } & \multicolumn{2}{|c|}{ Total food waste } & $\begin{array}{c}\text { Other waste } \\
(\mathbf{k g})\end{array}$ & $\begin{array}{c}\text { Total waste } \\
(\mathbf{k g})\end{array}$ & $\begin{array}{c}\text { Total waste per capita } \\
(\mathbf{g})\end{array}$ \\
\cline { 2 - 3 } & Person & $\mathbf{k g}$ & 40.5 & 178.5 & 357 \\
2 & 500 & 138.5 & 100.0 & 343.5 & 239 \\
3 & 1,440 & 243.5 & 17.0 & 60.0 & 343 \\
4 & 175 & 43.0 & 39.5 & 140.0 & 311 \\
5 & 450 & 100.5 & 92.5 & 311.0 & 259 \\
6 & 1,200 & 218.5 & 29.0 & 130.0 & 400 \\
7 & 300 & 91.0 & 93.0 & 178.0 & 375 \\
\hline
\end{tabular}

Table-2: Total availability of fruits\& vegetables processing waste in India

\begin{tabular}{|c|c|c|}
\hline S. No. & Fruits/vegetables & Quantity of wastes (000 tonnes) \\
\hline 1 & Mango & 3144.4 \\
2 & Banana & 823.3 \\
3 & Citrus & 606.0 \\
4 & Apple & 412.0 \\
5 & Potato & 146.0 \\
6 & Others & 214.0 \\
\hline \multicolumn{2}{|c|}{ Total } &
\end{tabular}

\section{Biogas generation from kitchen wastes}

The kitchen waste biogas plant is of the floating gas holder type. The basic principle of the design was obtained from SPRERI, Vallabh Vidyanagar, Gujarat. In this plant two gasholders were constructed with brick masonry and are additionally reinforced to prevent seepage. A central guide pipe helps in guiding the gas holder's movement. The kitchen waste is mixed with adequate quantity of water in a mixing tank. This is then fed to the digester via an inlet feed pipe. A slurry discharge channel is provided at the top to remove the digested slurry. The gasholder is fabricated using MS plate and angles. Diagonal mild steel bars are provided in the gas holder to serve as scum breakers (Prasad, 1997). 


\section{Potato processing waste provides biogas for steam production}

Potatoes are grown and consumed all over India. The potato processing industry in India is growing at a rate of $15-20 \%$ per year. The heat requirement for potato processing can be partially met by biomethanation of the potato waste generated. Anaerobic technology is very pertinent to India because atmospheric temperatures are suitable for anaerobic digestion almost throughout the year and across the country.

Table-3: Parameters for fruits \& vegetables processing waste based plants of various capacities

\begin{tabular}{|l|c|c|c|}
\hline Parameters & Domestic & Community & Industrial \\
\hline Digestor volume & $4 \mathrm{~m}^{3}$ & $50 \mathrm{~m}^{3}$ & $100 \mathrm{~m}^{3}$ \\
Waste handling capacity/day & $65 \mathrm{~kg}^{3}$ wet $)$ & $800 \mathrm{~kg}$ & $1.60 \mathrm{tonnes}^{2}$ \\
Space required & $5 \mathrm{~m}^{2}$ & $36 \mathrm{~m}^{2}$ & $65 \mathrm{~m}^{2}$ \\
Initial investment & $\mathrm{Rs} 14,400$ & $\mathrm{Rs} 1.80 \mathrm{lakhs}$ & $\mathrm{Rs} 3.00 \mathrm{lakhs}$ \\
(Subsidized 50\% capital) & $\mathrm{Rs} 7,200$ & $\mathrm{Rs} 90,000$ & $\mathrm{Rs} 1.50 \mathrm{lakhs}$ \\
daily biogas yield & $8 \mathrm{~m}^{3}$ & $100 \mathrm{~m}^{3}$ & $200 \mathrm{~m}^{3}$ \\
total energy generated/day & $37,704 \mathrm{kcals}$ & $4,71,30 \mathrm{kcals}$ & $9,42,600 \mathrm{kcals}$ \\
digested manure output/day & $25 \mathrm{~kg}(\mathrm{wet})$ & $320 \mathrm{~kg}$ & $640 \mathrm{~kg}$ \\
cost of production/m $\mathrm{m}^{3}$ of biogas & Rs 1.50 & Rs 2.00 & Rs 1.90 \\
payback period & 2 years & 3 years & 3 years \\
\hline
\end{tabular}

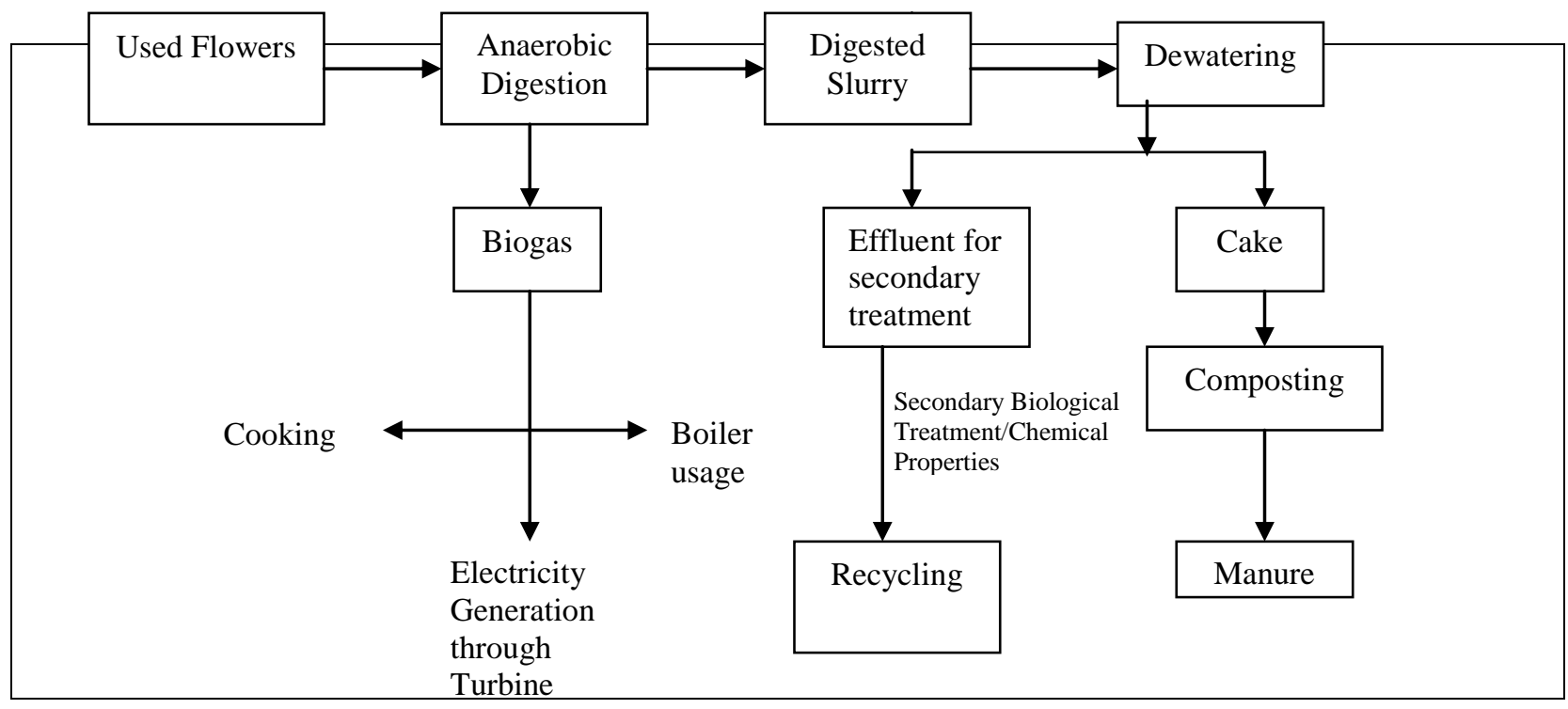

Fig.-1. Anaerobic Treatment of used Flowers

\section{Bio-energy from used flowers}

The used flowers in large quantities are found outside markets, temples and crematoria. Perfumeries extract perfumes from flowers and also generate flower wastes. The Arieff Research Centre, the R\&D wing of the Aireff de Tox inc., Thane, has developed a practical method to treat used flowers and recover biogas in the process consisting of feeding slurry of disposed flowers and water to the digester which is of the constantly stirred reactor type (CSTR). Separate reactor for acidification and methanation are not required. Flowers have good potential for biogas generation and in the Aireff process 400 cubic meters of biogas per tonne of waste is obtained. The reduction in the total solids contents upon 
digestion is around $80-85 \%$ (Kumari and Devidas, 1997).

\section{Biomethanation of pulp and paper mill waste}

Most of the paper mill discharging black liquor without or with partial treatment which contributes more than $80 \%$ of the total pollution loads as well as results in loss of valuable chemicals and huge amount of organic biomass which has a good potential for recovery of bioenergy. Biomethanation process as an alternate is now recognized as a proven technology for treatment of pulp and paper mill waste and number of full scale biomethanation plant based on UASB (Upward Anaerobic Sludge Blanket) process are working in pulp and paper mills world-wide.

\section{Soiled Currency Notes: a source of energy}

For several decades now, the Reserve Bank of India had been setting on fire soiled unusable currency notes. The bank routinely consigns to flames five billion notes weighing 4500 tonnes each year for want of a better method of "waste' disposal. However problems of emission and ash discharge into the atmosphere have induced the RBI to think of an eco-friendly method of 'soiled waste' disposal. The energy content in the soiled notes is also recovered in the process adopted by the RBI.

India has the distinction of being the world's largest disposer of mutilated currency notes. The life of the Indian rupee varies between six months and two years depending upon it's velocity of circulation. The soiled notes are withdrawn from circulation, examined, verified and defaced. In new technique adopted by the RBI, unusable currency notes are shredded and compressed into briquettes to realize their energy potential. Samples of briquettes have been made available to a number of interested parties and they are being tested for use as a fuel (Bio-energy News, 1997).

\section{Power generation from biogas}

For power generation, special biogasbased engines with automatic operational controls were imported from Jenbacher Energy System, Austria. This plant consists of two engines, each of $1003 \mathrm{KWe}$ rating. These engines have excellent combustion properties giving very low emission and are computer controlled, thereby requiring practically no man-power for supervision of their operation. The flue gases generated from the engines are further utilized to generate 1.7 tonnes of steam per hour at 10 bars in waste heat recovery units attached to each engine. The electrical power generated is connected to the existing electrical power supply system of the complex and the steam is used for process applications in different plants (Agrawal, 2000).

\section{Conclusions}

The waste generated by various food processing units, domestic and municipal waste, effluents of paper mills and biomass can be utilized to produce eco friendly energy and to reduce the hazards of environmental pollutions. The non-conventional energy sources may profitably replace the conventional energy input for farm operation. Potential of non-conventional energy sources needs to be harnessed to its greatest extent.

\section{References}

Agrawal, B.P. (2000). Waste - to - energy project at kanoria chemicals ltd. Ankleshwar. Bio-energy news, June, 7-8.

Bio-energy news (1997). 1(3): 5.

Kavita; Iyengar, S. and Nandini, S. (1997). Boienergy potential form food waste: a case study. Bio-energy news, 2(2): 9-10.

Kumari, P. and Devidas, S. (1997). Bio-energy form used flowers. Bio-energy news, 2(Dec.): 6-7.

Nand, K. (1997). CFTRI initiatives for energy generation from fruit and vegetable processing waste (news). Bio-energy news, 2 (2): 19-20.

Prasad, N. P. (1997). From concept to reality biogas generation from kitchen waste. Bio-energy news, 2(2): 16-17.

$\begin{array}{ll}\text { Received } & : \text { January, 2019 } \\ \text { Revised } & \text { : February, 2019 } \\ \text { Published } & : \text { June, 2019 }\end{array}$

